\title{
Effect of prepartum energy balance on neutrophil function following pegbovigrastim treatment in periparturient cows
}

\author{
S. McDougall, ${ }^{* 1}$ S. J. LeBlanc, $†$ and A. Heiserł \\ ${ }^{*}$ Cognosco, AnexaFVC, Morrinsville, 3300, New Zealand \\ †Ontario Veterinary College, University of Guelph, Guelph, ON, Canada N1G 2W1 \\ $\ddagger$ AgResearch, Hopkirk Research Institute, Palmerston North, 4442, New Zealand
}

\begin{abstract}
Treatment with granulocyte colony-stimulating factor (G-CSF) increases polymorphonuclear cell (neutrophil) count and enhances neutrophil function in the periparturient cow. Prepartum undernutrition was hypothesized to reduce the effect of a commercially available recombinant bovine G-CSF product (pegbovigrastim) on neutrophil count and function. Hence this study was undertaken to test the effect of undernutrition for approximately 1 mo before calving on the innate immune response to pegbovigrastim. Cows $(\mathrm{n}=$ 99) on pasture were blocked by expected calving date and body condition score and randomly assigned in a 2 $\times 2$ factorial design. The first factor was that cows were fed to exceed energy requirements prepartum (full feeding) or restricted to approximately $85 \%$ of prepartum energy requirements (restricted feeding). The second factor was that at approximately $7 \mathrm{~d}$ before expected calving date, half the cows in each feed group were injected with pegbovigrastim and the remaining half were injected with saline. Treatments were repeated on the day of calving. Blood samples were collected preand postcalving for complete blood count, biochemistry, and in vitro assessment of neutrophil function including phagocytosis, myeloperoxidase release, and oxidative burst. Prepartum energy restriction resulted in lower body weight, a higher proportion of cows with elevated concentrations (i.e., $>0.4 \mathrm{mmol} / \mathrm{L}$ ) of fatty acids, and higher average $\beta$-hydroxybutyrate concentrations before calving relative to fully fed cows. Treatment with pegbovigrastim increased the total white cell, neutrophil, lymphocyte, and monocyte counts. Pegbovigrastim treatment resulted in increased release of myeloperoxidase by neutrophils. Prepartum feeding group did not have an effect, and no feeding group $x$ treatment interaction was observed for any of the white cell counts or functional tests. We concluded that peg-
\end{abstract}

Received February 22, 2017.

Accepted April 22, 2017.

${ }^{1}$ Corresponding author: smcdougall@anexafvc.co.nz bovigrastim treatment results in significant increases in neutrophil count and enhances neutrophil function as indicated by increased myeloperoxidase release. The response to pegbovigrastim was not affected by restricted prepartum energy intake.

Key words: dairy cow, immune function, neutrophil, peripartum energy

\section{INTRODUCTION}

The risk of disease in dairy cows is high in the peripartum period (Ingvartsen et al., 2003). Polymorphonuclear cell (neutrophil) functionality decreases at this time, leading to increased susceptibility to mammary and uterine infections (Kehrli et al., 1989; Gilbert et al., 1993; Mallard et al., 1998). Neutrophils in the periparturient cow have reduced chemotaxis, phagocytosis, and oxidative burst (Ingvartsen and Moyes, 2013). The mechanisms for this reduced neutrophil function may include lack of nutrients and negative effects of increased concentrations of some blood metabolites as a result of tissue mobilization associated with negative energy balance (Kehrli et al., 1989; Ingvartsen and Moyes, 2013). Negative energy balance is associated with reduced neutrophil phagocytic function (Moyes et al., 2009). Elevated fatty acid concentrations are associated with changes in oxidative burst capacity of neutrophils (Scalia et al., 2006; Ster et al., 2012). Additionally, elevated BHB concentrations are associated with reduced chemotaxis, reduced milk leukocyte phagocytic activity (Kluciński et al., 1988; Suriyasathaporn et al., 1999), and reduced oxidative burst (Hoeben et al., 1997).

The production of neutrophils is regulated by granulocyte colony-stimulating factor (G-CSF; Semerad et al., 2002; Martin et al., 2003; Bendall and Bradstock, 2014). Granulocyte colony-stimulating factor is produced by a variety of cells including monocytes, macrophages, and cells of mesodermal origin including vascular endothelial cells, fibroblasts, and keratinocytes (Demetri and Griffin, 1991; Kehrli et al., 1991). It induces differentiation of progenitor cells into mature neutrophils, shortens maturation time within the bone 
marrow, and alters functionality by increasing phagocytosis and antibody-dependent cell-mediated cytotoxicity and by priming oxidation (Demetri and Griffin, 1991; Dale et al., 1995; Avalos, 1996).

Daily subcutaneous treatment with recombinant human G-CSF resulted in partial protection against intramammary challenge with Staphylococcus aureus (Nickerson et al., 1989). A long-acting analog of bovine G-CSF (pegbovigrastim injection, Imrestor, Elanco Animal Health, Greenfield, IN) is commercially available. Pegbovigrastim injection has been shown to increase neutrophil count in peripheral circulation and to increase neutrophil functionality in dairy cattle (Kimura et al., 2014; Hassfurther et al., 2015).

Studies conducted for regulatory approval in New Zealand, the United States, and Europe have demonstrated a lower clinical mastitis incidence in early lactation following pegbovigrastim treatment. However, the magnitude of reduction in mastitis incidence varied substantially between farms. The reasons for this variation is unclear, but one hypothesis is that the response to pegbovigrastim, similar to neutrophil function itself, may be influenced by the metabolic status of the cow, specifically the degree of negative energy balance experienced during the periparturient period.

The objective of this study was to test the hypothesis that response to pegbovigrastim, as assessed by neutrophil count and in vitro neutrophil functional assays, is modulated by negative energy balance in the peripartum period.

\section{MATERIALS AND METHODS}

The study was undertaken following approval of the animal ethics committee of AgResearch, Ruakura, New Zealand. Multiparous cows ( $\mathrm{n}=99 ; 48$ Holstein Frie- sians, 13 Jerseys, and 38 Holstein Friesian $\times$ Jersey) on pasture all the time at a research dairy facility (Massey University, Palmerston North, New Zealand) were enrolled. Cows were blocked by week of expected calving, ranked on BCS, and randomly assigned within block in a $2 \times 2$ factorial design.

On 3 occasions, at weekly intervals, cows due to calve in 4 to 5 wk were assessed by a veterinarian, and cows with grossly evident signs of disease were excluded (n $=2$; Figure 1). Remaining cows were assigned to either a full ration $(\mathbf{F R})$ or restricted ration $(\mathbf{R R})$ at 31.4 $(\mathrm{SD}=5.5)$ and $30.9(\mathrm{SD}=4.9) \mathrm{d}$ before calving, respectively. The FR cows were offered (on a DM basis) $2 \mathrm{~kg}$ of pasture [ryegrass (Lolium perenne)/white clover (Trifolium repens)], $3.2 \mathrm{~kg}$ of pasture hay, $6.1 \mathrm{~kg}$ of maize silage, and $0.2 \mathrm{~kg}$ of a trace element vitamin mix (NutriMin Springer cow balancer Hi Mg, Nutritech International Ltd., New Zealand, batch number 506072) per cow per day. This ration was calculated (Rumen8, Department of Agriculture, Western Australia; http:// www.rumen8.com.au/) to provide approximately 120 MJ of ME per cow per day, or $122 \%$ of prepartum energy requirements. The RR group was offered $1.33 \mathrm{~kg}$ of pasture (ryegrass/white clover), $2.3 \mathrm{~kg}$ of pasture hay, $4.2 \mathrm{~kg}$ of maize silage, and $0.2 \mathrm{~kg}$ of trace element vitamin mix per cow per day. This diet provided approximately $82 \mathrm{MJ}$ of ME per cow per day, or $85 \%$ of prepartum energy requirements.

Cows were managed by placing temporary electric fencing longitudinally down a paddock and feeding the 2 groups side by side. The area of pasture offered was adjusted to ensure that the required intakes were achieved. The maize silage, hay, and trace element mix was fed once daily in concrete troughs near the dairy parlor. The 2 feed groups were fed separately, but using the same feed mix. The feed was mixed in a wagon

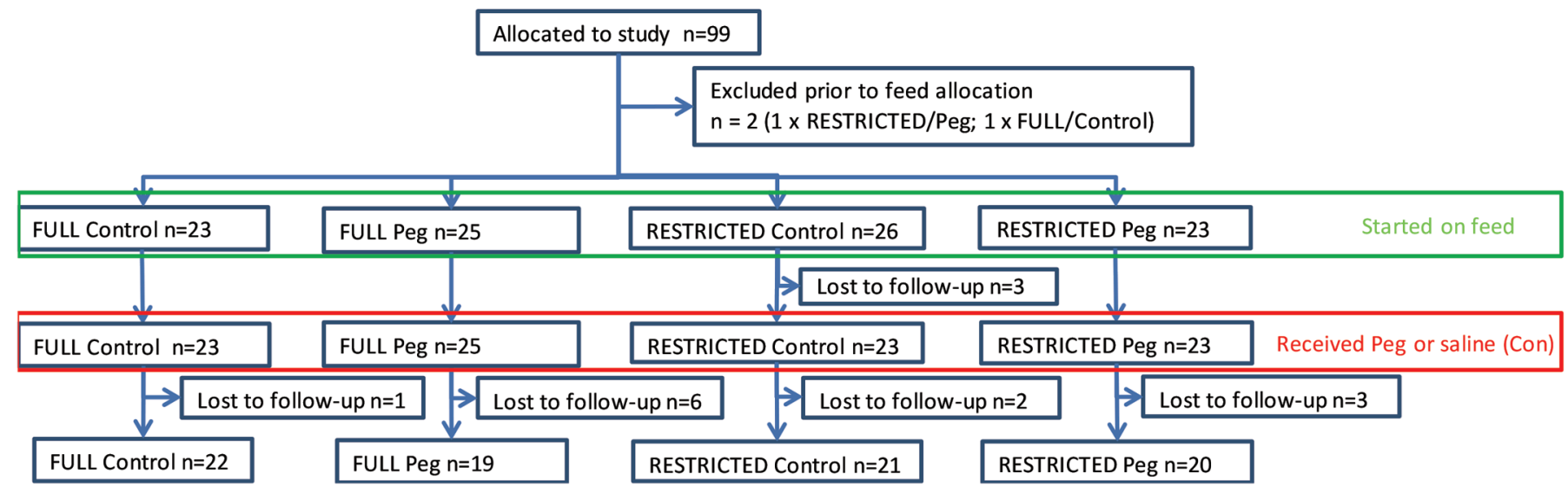

Figure 1. Number and fate of cows allocated to restricted ration or full ration feeding precalving and either pegbovigrastim (Peg) or saline (Control) at approximately $7 \mathrm{~d}$ before due calving date and the day of calving. Color version available online. 
that had incorporated scales, and the mass mixed was recorded each day.

Postpartum, the 2 precalving feed groups were cograzed and were offered the same ration, designed to support a peak milk yield of $25 \mathrm{~L} /$ cow per day and limit BW loss to $<0.2 \mathrm{~kg} / \mathrm{d}$ over the first month of lactation. The ration offered was (DM basis) $9 \mathrm{~kg}$ of pasture (ryegrass/white clover), $2 \mathrm{~kg}$ of a commercial dairy pellet (Starch Blend, Seales Winslow, Tauranga, New Zealand), $3 \mathrm{~kg}$ of palm kernel expeller, $1 \mathrm{~kg}$ of pasture silage, $2.5 \mathrm{~kg}$ of maize silage, and $0.2 \mathrm{~kg}$ of the mineral vitamin mix per cow per day.

Estimates of entry pasture cover, residual pasture cover, and area per cow were calculated daily for each treatment group prepartum and fortnightly postpartum. The pasture mass present ( $\mathrm{kg}$ of $\mathrm{DM} / \mathrm{ha}$ ) before and after grazing was estimated using a rising plate meter (Earle and McGowan, 1979). Briefly, a calibrated plate mounted so that it could be displaced vertically upwards on a shaft, and with an inbuilt calibrated measure of vertical displacement, was used to take multiple estimates of pasture height relative to the ground across a paddock. The pasture height has been calibrated with the DM of pasture obtained by harvesting the pasture to ground level in a defined area, oven drying, and weighing of the material. The DM of pasture ingested daily was calculated by subtracting the residual pasture mass from the starting pasture mass, dividing this by the number of animals in the group, and multiplying by the area (in hectares). The pasture composition (i.e., proportion of ryegrass and white clover in the sward) was not formally assessed, but the pasture was originally sown with these species and both were visually present. Pasture samples were submitted for analysis twice, and a hay and maize silage on one occasion, for near infrared spectroscopy (Hills Laboratory, Hamilton, New Zealand). The metabolizable energy and metabolizable protein intakes were calculated by multiplying the estimated mass of each feed type consumed by the metabolizable energy and protein values obtained from the laboratory analyses.

At approximately 7 to $10 \mathrm{~d}$ before anticipated calving, cows were injected subcutaneously with $15 \mathrm{mg}$ in $2.7 \mathrm{~mL}$ injection volume of the pegylated form of recombinant bovine G-CSF (pegbovigrastim injection, Imrestor, Elanco Animal Health) or $3 \mathrm{~mL}$ of $0.9 \% \mathrm{NaCl}$ (control). A second injection of the same treatments occurred at the first milking (i.e., within $24 \mathrm{~h}$ ) after calving (d 0).

Body weight was assessed 28, 14, and $7 \mathrm{~d}$ before expected calving due date and daily through to $4 \mathrm{wk}$ after calving. Body condition score was assessed at 28, 14, and $7 \mathrm{~d}$ before the expected calving due date and at 0 , 7, 21, and 28 d postpartum, on a 1 to 10 scale (Roche et al., 2004). These data may be converted to the US ( 1 to 5 ) scale by multiplying the New Zealand score by 0.32 and adding 1.5 (Roche et al., 2004).

Blood samples were drawn from the tail vessels at $28,14,7$, and $6 \mathrm{~d}$ before the expected calving date and at $0,4,7$, and $21 \mathrm{~d}$ postpartum into evacuated glass containers containing EDTA (Becton Dickinson, Franklin Lakes, NJ), fluoroacetate (d -7 and d 0 only) and with no anticoagulant (other than on $d-6$ ). Samples were drawn in the morning before supplements were fed, held at ambient temperature, and transported to the laboratory within $2 \mathrm{~h}$. On d 0 , cows were milked for the first time between approximately 1500 and 1700 $\mathrm{h}$. They were treated and blood sample were taken at this time.

\section{Laboratory Procedures}

The number and type of red and white blood cells (complete blood count) was determined using an automated hemocytometer (Sysmex XT2000i, Roche Diagnostics, Auckland, New Zealand), and cell morphology was assessed by microscopic examination of blood smears.

Blood samples drawn on $\mathrm{d}-7, \mathrm{~d}+4$, and $\mathrm{d}+7$ were analyzed for neutrophil function using phagocytosis, myeloperoxidase (MPO), and reactive oxygen species production in vitro tests.

Neutrophil Preparation from Peripheral Blood. Within $1 \mathrm{~h}$ of the blood samples being drawn, neutrophils were prepared from whole blood samples using a method modified from Roth and Kaeberle (1981). For ease and speed of the procedure, the separation by density gradient was omitted. Briefly, blood was transferred into $50-\mathrm{mL}$ conical tubes and centrifuged at 1,500 $\times \mathrm{g}$ for $30 \mathrm{~min}$ at room temperature. After centrifugation, the plasma, buffy coat layer, and top layer (approximately $1 / 3$ ) of packed red blood cells were removed. To the remaining cells, $40 \mathrm{~mL} /$ tube of red blood cell lysis buffer (Tris-buffered ammonium chloride) was added, and tubes were incubated for $10 \mathrm{~min}$ at $37^{\circ} \mathrm{C}$ in a water bath. Subsequently, cells were centrifuged at $600 \times g$ for $10 \mathrm{~min}$, washed once in PBS (10 $\mathrm{mM}$, $\mathrm{pH} 7.4)$, and resuspended in Hanks' buffered salt solution (HBSS, ThermoFisher, Waltham, MA) at $2.5 \times 10^{7}$ cells $/ \mathrm{mL}$. Cell suspensions prepared using this procedure had $\geq$ $80 \%$ pure populations of neutrophils as confirmed by Kwik-Diff staining (ThermoFisher).

Phagocytosis Assay. The ability of blood-derived neutrophils to phagocytose $S$. aureus was determined by flow cytometric detection of fluorescein isothiocyanate (FITC)-labeled bacteria (S. aureus BioParticles, FITC conjugated, ThermoFisher). Two tubes were prepared from each neutrophil sample, each containing $1.25 \times$ 
$10^{6}$ cells $/ 50 \mu \mathrm{L}$. To one tube, $50 \mu \mathrm{L}$ of BioParticles (i.e., $1.5 \times 10^{7}$ particles, $\sim 12$ particles/cell) were added. Tubes were gently mixed and incubated at $37^{\circ} \mathrm{C}$ for 20 min. After 2 washes with $3 \mathrm{~mL}$ of cold PBS per tube and centrifugation at $350 \times g$ for $7 \mathrm{~min}$ at $4^{\circ} \mathrm{C}$, cells were fixed by resuspending in $500 \mu \mathrm{L}$ of PBS with $3 \%$ paraformaldehyde and incubating for $5 \mathrm{~min}$ at $4^{\circ} \mathrm{C}$ in the dark. Fixation of cells was completed no later than $2 \mathrm{~h}$ after drawing the blood samples. After 1 wash with $3 \mathrm{~mL}$ of cold PBS and centrifugation at $350 \times g$ for 7 min at $4^{\circ} \mathrm{C}$, the cells were resuspended in $150 \mu \mathrm{L}$ of PBS with $3 \%$ fetal calf serum. Samples were kept in the dark and refrigerated until analysis. Approximately 30 s before acquisition, $100 \mu \mathrm{L}$ of quenching solution [250 $\mu \mathrm{g} / \mathrm{mL}$ trypan blue (Sigma, St. Louis, MO) in PBS) was added per tube. Samples were acquired with a flow cytometer (FACSCalibur, BD Biosciences, San Jose, CA) with blue laser excitation at $488 \mathrm{~nm}$ and absorption measured at $530 \mathrm{~nm}$. Results were analyzed using FlowJo software (TreeStar, Ashland, OR). The percentage of phagocytosis-positive cells was determined by comparison with fluorescence of the same neutrophil preparation without BioParticles. Mean fluorescence intensity (MFI) was also determined for FITC-positive cells as an index of number of $S$. aureus ingested by neutrophils.

Myeloperoxidase Assay. Myeloperoxidase release was measured from unstimulated, phorbol 12-myristate 13-acetate (PMA)-stimulated, and lysed neutrophils (Palić et al., 2005). Duplicates of $1.25 \times 10^{6}$ cells $/ 50 \mu \mathrm{L}$ per well were combined with either $50 \mu \mathrm{L} /$ well of HBSS (unstimulated control), $50 \mu \mathrm{L} /$ well of stimulation reagent, or $50 \mu \mathrm{L} /$ well lysis reagent $[0.02 \%$ hexadecyltrimethylammonium bromide (Sigma) in water] in 96-well flat-bottom plates. Stimulation reagent was prepared by mixing 1 part of CaI stock solution [50 $\mu \mathrm{g} / \mathrm{mL}$ calcium ionophore A23187 (Sigma) in HBSS], 1 part of cytochalasin B stock solution [50 $\mu \mathrm{g} / \mathrm{mL}$ cytochalasin B (Sigma) in HBSS], 1 part of PMA stock solution [20 $\mu \mathrm{g} / \mathrm{mL}$ PMA (Sigma) in HBSS], and 7 parts of HBSS. Plates were incubated at $30^{\circ} \mathrm{C}$ for $60 \mathrm{~min} .3,3^{\prime}, 5,5^{\prime}$-Tetramethylbenzidine (Becton Dickinson) and hydrogen peroxide were mixed $1: 1$, and $100 \mu \mathrm{L}$ of the mixture was added to each well. Color was allowed to develop at room temperature for approximately 2 min before $50 \mu \mathrm{L}$ of stop reagent $\left(2 \mathrm{~N} \mathrm{H}_{2} \mathrm{SO}_{4}\right)$ was added. Plates were centrifuged at $600 \times g$ for $5 \mathrm{~min}$ at room temperature, and $150 \mu \mathrm{L} /$ well was transferred into a new plate. Optical density (OD) at $405 \mathrm{~nm}$ was determined using microtiter plate spectrophotometer (Versamax, Molecular Devices, Sunnyvale, CA). The percentage of MPO released from neutrophils was determined for each sample using MPO release $(\%)=(\mathrm{OD}$ of PMA- stimulated sample - OD of control sample)/(OD of lysed sample - OD of control sample) $\times 100$.

Respiratory Burst Assay. Reactive oxygen species were analyzed using cytochrome c reduction as described previously (Roth et al., 2001). Duplicates of $2.5 \times 10^{6}$ cells $/ 100 \mu \mathrm{L}$ per well were combined with either $50 \mu \mathrm{L} /$ well of HBSS (unstimulated control) or $50 \mu \mathrm{L} /$ well of PMA solution $(20 \mu \mathrm{g} / \mathrm{mL}$ PMA; stimulated samples) in 96-well flat-bottom plates. All wells also received $50 \mu \mathrm{L}$ of cytochrome c solution $[2 \mathrm{mg}$ of cytochrome c (Sigma) per milliliter of HBSS). Plates were incubated at $37^{\circ} \mathrm{C}$ for $20 \mathrm{~min}$ and centrifuged at $600 \times g$ for $10 \mathrm{~min}$ at room temperature, and $150 \mu \mathrm{L} /$ well was transferred into a new plate. Optical density at 550 and $650 \mathrm{~nm}$ was determined using microtiter plate spectrophotometer (Versamax). Reactive oxygen species release $(\mathrm{OD})$ was calculated from $\left(\mathrm{OD}_{550}\right.$ of PMA-stimulated sample $-\mathrm{OD}_{650}$ of PMA-stimulated sample $)-\left(\mathrm{OD}_{550}\right.$ of control sample $-\mathrm{OD}_{650}$ of control sample).

Other Laboratory Procedures. The blood total calcium concentration was assessed on d 0 (i.e., day of calving) and $\mathrm{d}+7$, fatty acids on $\mathrm{d}-28, \mathrm{~d}-14, \mathrm{~d}-7, \mathrm{~d}$ $0, \mathrm{~d}+4$, and $\mathrm{d}+7$, and BHB on $\mathrm{d}-28, \mathrm{~d}-7, \mathrm{~d}+4$, and $\mathrm{d}$ +7 . The biochemistry was undertaken by New Zealand Veterinary Pathology, Palmerston North, New Zealand, using the 5-nitro-5'-methyl-BAPTA (Calcium Gen.2 P, Roche Diagnostics, Auckland, New Zealand), oxidation of D-3-hydroxybutyrate to acetoacetate by the enzyme 3-hydroxybutyrate dehydrogenase and $\mathrm{NAD}^{+}$reduction to NADH (in-house assay, reagents supplied by Sigma Aldrich), ACS-ACOD-MEHA including maleimide (WAKO NEFA C kit, VWR International, Radnor, PA) methodologies for calcium, BHB, and fatty acids, respectively, on a Roche 800 analyzer.

\section{Statistical Analyses}

The statistical analysis was performed using SPSS (version 22, IBM, Armonk, NY) or Stata (version 14.1; Stata.com). The level of significance was set to $P<$ 0.05. Two-sided tests were used for comparing the main effects within an analysis.

The primary outcomes were the neutrophil count and neutrophil MPO, reactive oxygen species generation, and phagocytosis function. Complete blood count data were analyzed using repeated-measures ANOVA models with time (day relative to calving) nested within cow and with cow as a random effect. Main effects included treatment, feed group, and time (day). The first interactions of the main effects were tested and remained in the model where significant $(P<0.05)$. The data are presented as covariate adjusted (marginal) estimated 
means, and the effects compared using the Bonferroni adjustment for multiple comparisons.

The neutrophil function data were log 10 transformed and analyzed using GLMM with treatment (pegbovigrastim vs. control), precalving feed group (FR vs. $\mathrm{RR}$ ), and time (i.e., $\mathrm{d}-7, \mathrm{~d}+4, \mathrm{~d}+7$ ) as the main effects, and their first-order interactions were included in the models. Time was nested within cow, which was treated as a random effect. The covariate adjusted (marginal) means were calculated for each main effect, and the levels within each effect compared using pairwise comparisons, using a Bonferroni adjustment for multiple comparisons where appropriate.

Body condition score and BW were analyzed using repeated measures generalized linear model with treatment, feed, and time as the main effects. The first-order interaction of feed $\times$ time was included in the models. For BW precalving, weights were expressed as a percentage of the first (i.e., $\mathrm{d}-28)$ weight, that is, $(\mathrm{BW} \mathrm{d}$ $-28-\mathrm{BW}$ on day)/(BW on $\mathrm{d}-28)$.

Fatty acid and BHB data were log 10 transformed because they were not normally distributed. Additionally, data were categorized as normal or high (i.e., $>0.4$ or $>1.0 \mathrm{mmol} / \mathrm{L}$ defined as high for fatty acids prepartum and postpartum, respectively, LeBlanc 2012, Ospina et al., 2013; and $>0.8$ or $>1.4 \mathrm{mmol} / \mathrm{L}$ defined as high for BHB prepartum and postpartum, respectively, Ospina et al., 2013; Compton et al., 2015). The continuous data were analyzed using repeated measure (time within cow) random intercept models and the dichotomous data by Fisher's exact test within day. The design variables of treatment, feed group, and day relative to calving were included in each model. First- and secondorder interactions were tested and retained if $P<0.05$. Pairwise comparisons of levels within significant main effects were tested. The log-transformed continuous data are presented as exponentiated marginal means.

The calcium concentrations were analyzed using repeated measures random intercept models, and the main effects and first-order, and second-order interactions were tested as above.
Kimura et al. (2014) demonstrated that pegbovigrastim increased the percentage of MPO released from stimulated neutrophils from $45 \%(\mathrm{SD}=16)$ to $65 \%$ $(\mathrm{SD}=10)$ at $\mathrm{d}+1$ and $\mathrm{d}+4$ postpartum. To assess if negative energy balance reduced the percentage release of MPO to $57 \%$ (compared with $65 \%$ in the FR cows), 20 animals were required per treatment group, assuming a one-sided test and a power of $80 \%$. That is, underfeeding (RR feed group) was hypothesized to result in an approximate halving of the increase in MPO released percentage compared with that achieved by pegbovigrastim in FR cows.

\section{RESULTS}

The disposition of cows from initial enrolment to final analyses is described in Figure 1.

\section{Group Balance}

For the 82 cows remaining in the study, no difference was observed in the calving date or parity among the feed or treatment groups (Table 1). Additionally, treatment groups did not differ in the breed distribution, with $41(50 \%), 33(40.2 \%)$, and $8(9.8 \%)$ of the 82 cows defined as Friesian, cross bred, or Jersey. The actual day of enrollment (i.e., $\mathrm{d}-28$ ) and the day of treatment (i.e., d -7 ) did not differ by feed or treatment group. The timing of scheduled visits was actually -31.1 (SD $=5.2),-17.2(\mathrm{SD}=5.4),-10.9(\mathrm{SD}=5.5), 0.0(\mathrm{SD}$ $=0.0), 6.8(\mathrm{SD}=0.7), 21.1(\mathrm{SD}=2.0)$, and $26.8(\mathrm{SD}$ $=0.8$ ) days relative to calving for visits scheduled for $\mathrm{d}$ $-28, \mathrm{~d}-14, \mathrm{~d}-7, \mathrm{~d} 0, \mathrm{~d}+7, \mathrm{~d}+21$, and $\mathrm{d}+28$ relative to calving, respectively. The actual day of sampling did not vary among treatment $(P=0.72)$ or feed groups $(P=0.64)$.

\section{Nutrition}

Cows in the RR diet were offered approximately $85 \%$ of prepartum daily metabolizable energy requirement

Table 1. Mean (and SD) calving date, parity, and day of enrollment and $\mathrm{d}-7$ for cows fed either a restricted ration (RR) or full ration (FR) before calving and treated ( $\mathrm{Rx}$ ) with pegbovigrastim (Peg) or with saline (Con) at approximately $\mathrm{d}-7$ relative to calving and on the day of calving

\begin{tabular}{|c|c|c|c|c|c|c|c|c|c|c|c|}
\hline \multirow[b]{2}{*}{ Item } & \multicolumn{2}{|c|}{ RR Con } & \multicolumn{2}{|c|}{ RR Peg } & \multicolumn{2}{|c|}{ FR Con } & \multicolumn{2}{|c|}{ FR Peg } & \multicolumn{3}{|c|}{$P$-value ${ }^{1}$} \\
\hline & Mean & $\mathrm{SD}$ & Mean & $\mathrm{SD}$ & Mean & $\mathrm{SD}$ & Mean & $\mathrm{SD}$ & Feed & $\mathrm{Rx}$ & Feed $\times \mathrm{Rx}$ \\
\hline Parity & & 2.0 & 4.0 & 2.1 & 3.8 & 1.4 & 3.9 & 1.7 & 0.45 & 0.83 & 0.65 \\
\hline$d-28^{2}$ & -31.0 & 5.3 & -30.8 & 4.7 & -30.5 & 6.0 & -32.3 & 4.9 & 0.76 & 0.28 & 0.89 \\
\hline $\mathrm{d}-7^{2}$ & -11.1 & 5.9 & -10.4 & 5.2 & -10.6 & 6.3 & -11.7 & 5.0 & 0.78 & 0.55 & 0.69 \\
\hline
\end{tabular}

${ }^{1}$ The $P$-value is from a generalized linear model.

${ }^{2}$ Relative to expected calving date. 
Table 2. Estimate of feed intake and macro and micro element intakes for cows on a full ration (FR) or restricted ration (RR) before calving and in early lactation ${ }^{1}$

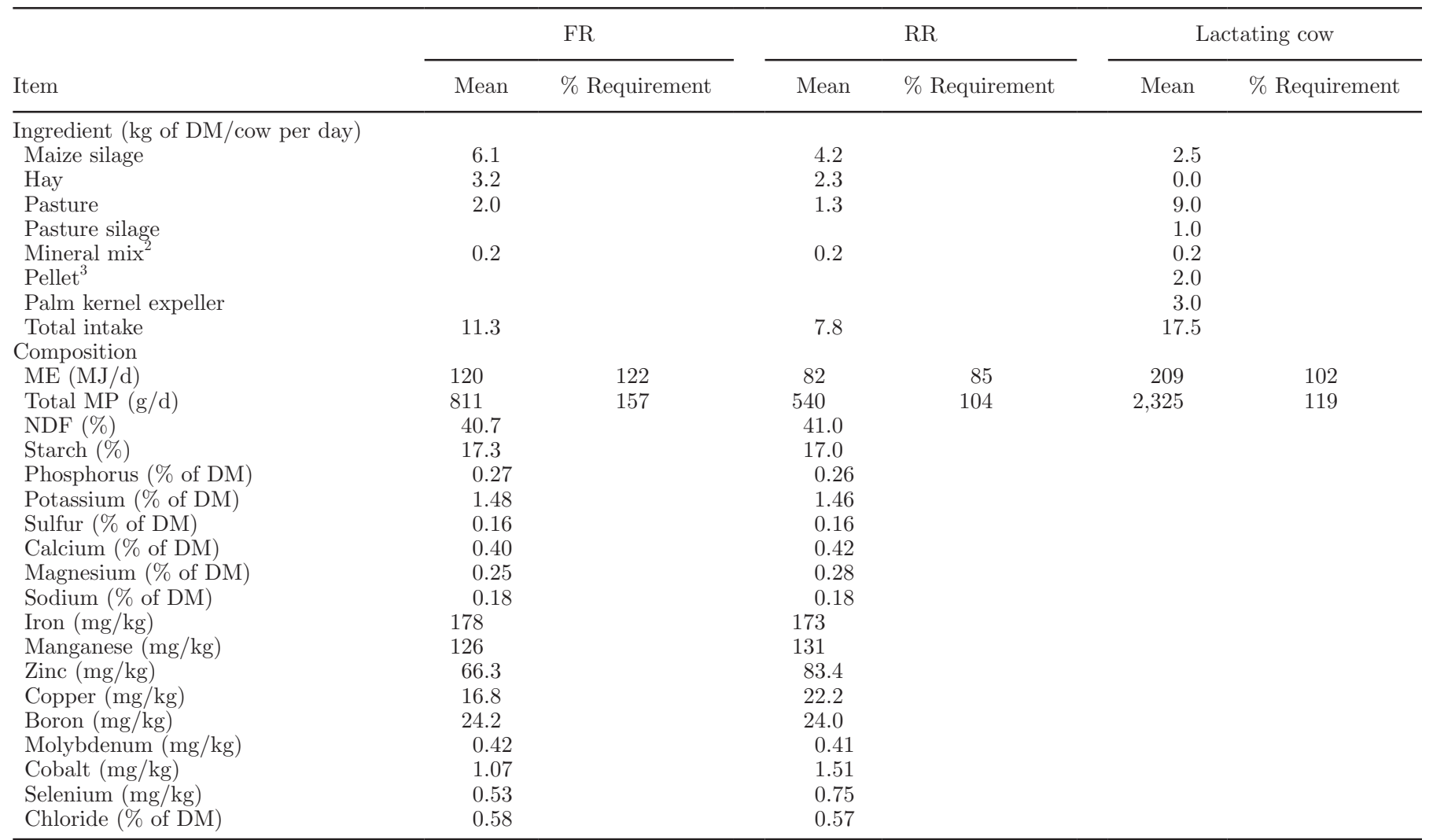

${ }^{1}$ The prepartum data are a summary of 48 daily assessments of the amount of feed offered. The ME and MP are calculated based on near infrared spectroscopy assessments of 3 pasture samples and 1 hay and silage sample.

${ }^{2}$ Nutrimin Springer Cow Balancer, Nutritech Auckland, New Zealand.

${ }^{3}$ Starch Blend, Seales Winslow, Tauranga, New Zealand.

and $104 \%$ of metabolizable protein requirements, while the FR group was offered $122 \%$ and $157 \%$ of metabolizable energy and protein requirements, respectively (Table 2). Following calving, all study cows were managed together and offered the same feed (Table 2).

\section{BCS}

Overall BCS tended to be lower for the RR than FR group ( $3.99 \pm 0.03$ vs. $4.07 \pm 0.03 ; P=0.08)$, but it did not differ between treatment groups $(P=0.72)$. Body condition score changed over time, with BCS from d 0 to +28 being significantly lower than BCS at d -28 .

\section{BW}

Precalving $\boldsymbol{B} \boldsymbol{W}$. The precalving BW was lower in the $\mathrm{RR}$ group relative to the $\mathrm{FR}$ feed group $(P<0.001)$ on $\mathrm{d}-14[95.4 \%(\mathrm{SE}=0.3)$ vs. $101.1 \%(\mathrm{SE}=0.3)]$, $\mathrm{d}$ $-7[96.0 \%(\mathrm{SE}=0.4)$ vs. $101.0 \%(\mathrm{SE}=0.4)]$, and $\mathrm{d} 0$ $[96.1 \%(\mathrm{SE}=0.4)$ vs. $101.0 \%(\mathrm{SE}=0.5)]$.
Postpartum $\boldsymbol{B} \boldsymbol{W}$. Following calving, BW did not differ between treatment group $(P=0.75)$ or feed group $(P=0.99)$. However, BW declined with time postpartum, with live weight between $\mathrm{d}+5$ and $\mathrm{d}+30$ being significantly lower than the day of calving (d 0 ; Figure 2). We found no interaction of time $\times$ feed for postpartum BW.

\section{Hematology}

White Blood Cell Count. A treatment $\times$ time interaction was observed whereby the white blood cell count was higher in pegbovigrastim-treated cows than in control cows from d -6 onwards (Figure 3a). Feed group was not significant, and no interactions occurred between feed group and treatment or feed group and time (both $P>0.2$ ).

Neutrophil Count. A treatment $\times$ time interaction occurred whereby the neutrophil count was higher in pegbovigrastim-treated cows compared to control cows from $d-6$ onwards (Figure $3 \mathrm{~b}$ ). Feed group was not 
significant, and no interactions occurred between feed group and treatment or feed group and time (both $P$ $>0.2$ ).

Lymphocyte Count. Lymphocyte count was overall higher in pegbovigrastim-treated cows than in control cows $[3.2(\mathrm{SE}=0.1)$ vs. $2.7(\mathrm{SE}=0.1) ; P=0.04]$. It changed with time, and a treatment $\times$ time interaction was observed (Figure 3c). Feed group was not significant, and no interactions were seen between feed and treatment or feed and time (both $P>0.2$ ).

Monocyte Count. A treatment $\times$ time interaction was observed for monocyte count (Figure 3d). Feed group was not significant, and no interactions occurred between feed group and treatment or feed group and time (both $P>0.2$ ).

White Blood Count Differential. A treatment $\times$ time interaction occurred for the percentage of each white cell type (other than for basophils; Table 3). Feed group did not affect the white cell count differential counts.

Red Blood Cell Count. The red blood cell count varied by time (Figure 4a). A time $\times$ treatment interaction occurred whereby the $\mathrm{d}+7$ and $\mathrm{d}+21$ counts were lower in the pegbovigrastim-treated group than in the control group (Figure 4a). Feed group had no effect, and no interactions were observed for feed group $\times$ treatment or feed group $\times$ time (both $P>0.2$ ).

Hematocrit. The hematocrit varied by time (Figure 4b). A time $\times$ treatment interaction was observed, with hematocrit at $\mathrm{d} 0$ to +21 being lower in the pegbovi- grastim-treated group than in the control group (Figure 4b). Feed group had no effect, and no interactions were observed for feed group $\times$ treatment or feed group $\times$ time (both $P>0.2$ ).

Mean Cell Volume, Mean Cell Hemoglobin, and Mean Cell Hemoglobin Concentration. No associations were observed between mean cell volume and treatment $(P=0.77)$, feed group $(P=0.56)$, or time $(P=0.18)$. No associations were apparent between mean cell hemoglobin and treatment $(P=0.94)$, feed group $(P=0.51)$, or time $(P=0.89)$. No associations were observed between mean cell hemoglobin concentration and treatment $(P=0.25)$ or feed group $(P=$ 0.72 ), but mean cell hemoglobin concentration varied across time with $\mathrm{d}-28$ being lower than $\mathrm{d}-14$ and $\mathrm{d}$ $+21(P<0.01)$.

\section{Neutrophil Function}

Phagocytosis. Phagocytosis declined with time ( $P$ $<0.001$ ), but it was unaffected by treatment, feeding, or their interaction (Figure 5a). The MFI for phagocytosis declined with time, but there were also interactions of treatment $\times$ time (as the pegbovigrastim group was lower at $d+7$ than at $d-7$, but there was no effect of time in the saline group), and feed $\times$ time (as the MFI was lower at $d+4$ and +7 than at $d-7$ for the $R R$ group, but not different across time for the for the FR group) for this outcome variable (Figure 5b).

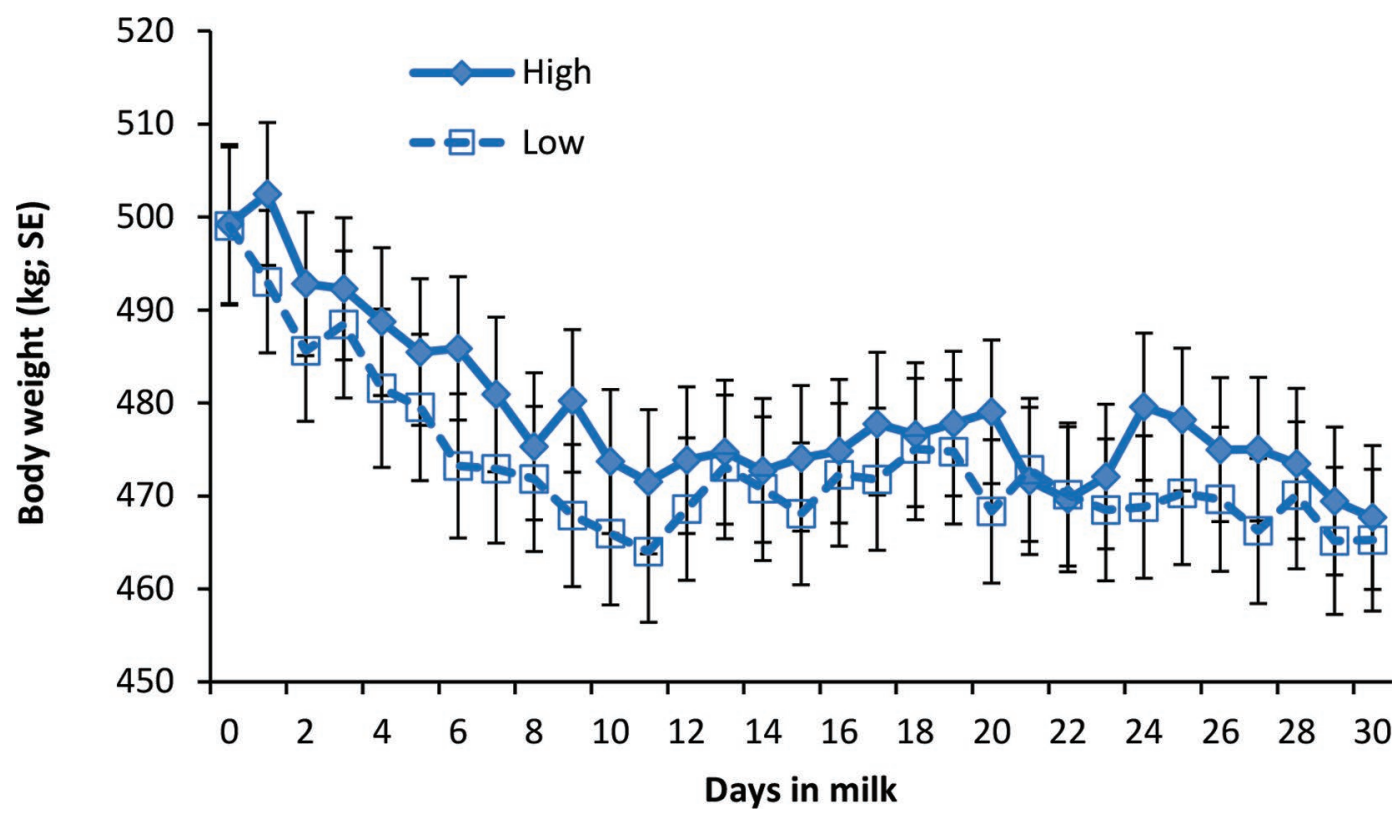

Figure 2. Covariate-adjusted (marginal) mean (SE) of postpartum BW by feeding group from a generalized linear model, which included treatment group, feed group, DIM, parity (1-9), and breed (categorized as Friesian, cross bred, or Jersey). Color version available online. 
(a)

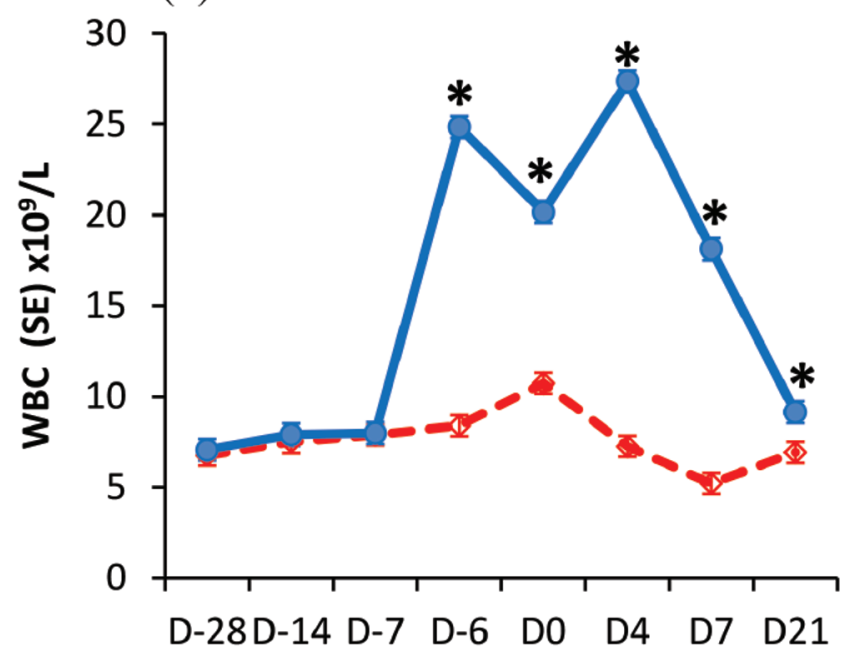

(c)

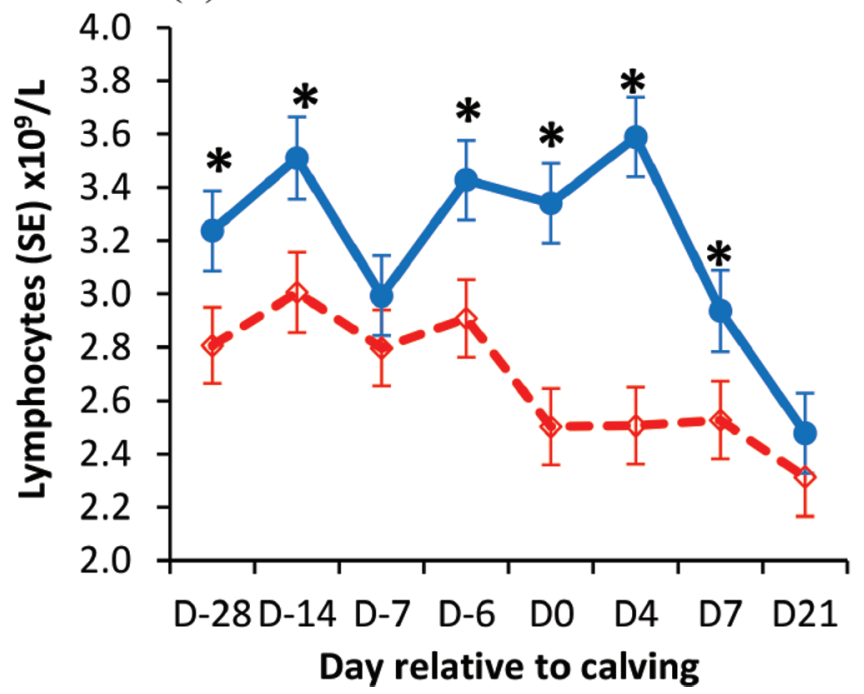

(b)

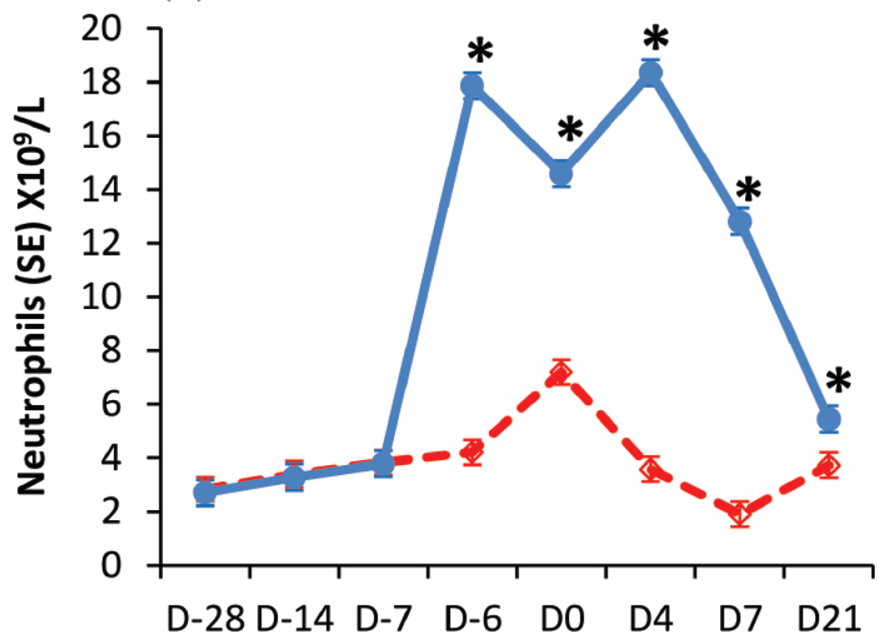

(d)

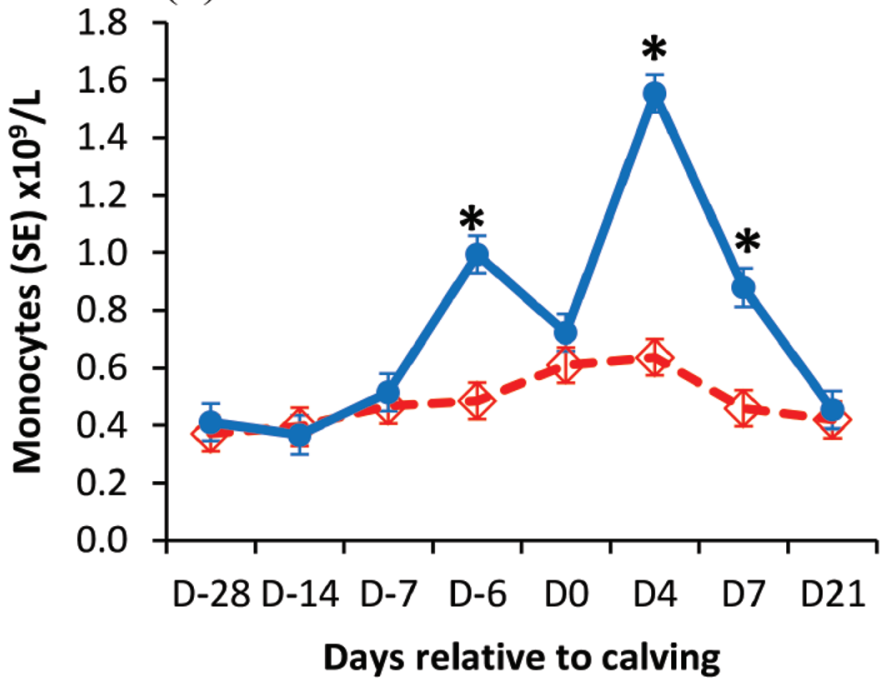

Figure 3. Covariate-adjusted (marginal) mean (SE) count of (a) white blood cells (WBC; $\left.\times 10^{9} / \mathrm{L}\right)$, (b) neutrophils $\left(\times 10^{9} / \mathrm{L}\right)$, (c) lymphocytes $\left(\times 10^{9} / \mathrm{L}\right)$, and $(\mathrm{d})$ monocytes $\left(\times 10^{9} / \mathrm{L}\right)$, for cows treated with pegbovigrastim (solid line) on $\mathrm{d}-7$ and $\mathrm{d} 0$ compared with cows treated with saline (dashed line). The asterisks indicate differences $(P<0.05)$ between pegbovigrastim and saline-treated cows on that day. Color version available online.

Oxidative Burst. Oxidative burst was unaffected by treatment, feeding, or time, and no first-order interactions were observed (Figure 5c).

Myeloperoxidase Function. All 3 measures of MPO function were significantly affected by treatment and time, and a treatment $\times$ time interaction was observed for each of these parameters (Figures 5 d,e,f). Overall, the basal MPO was lower in pegbovigrastimtreated cows than in saline-treated cows $(P<0.001)$, and MPO declined with time $(P<0.001)$. A treatment $\times$ time interaction was observed $(P<0.001)$, with the pegbovigrastim-treated cows having lower basal MPO at $\mathrm{d}+4$ in the $\mathrm{RR}$ cows and at $\mathrm{d}+7$ in both $\mathrm{RR}$ and FR cows.

Similarly, the stimulated MPO was lower in pegbovigrastim-treated cows than in saline-treated cows $(P$ $<0.001)$, and MPO declined with time $(P<0.001)$. A treatment $\times$ time interaction was observed $(P<$ 0.001 ), with the pegbovigrastim-treated cows having lower MPO than controls at $d+7$, but not at $d-7$ or $\mathrm{d}+4$.

Overall, pegbovigrastim treatment increased the release of MPO $(P=0.03)$, and a treatment $\times$ time interaction occurred $(P<0.001)$, with the pegbovigrastim- 

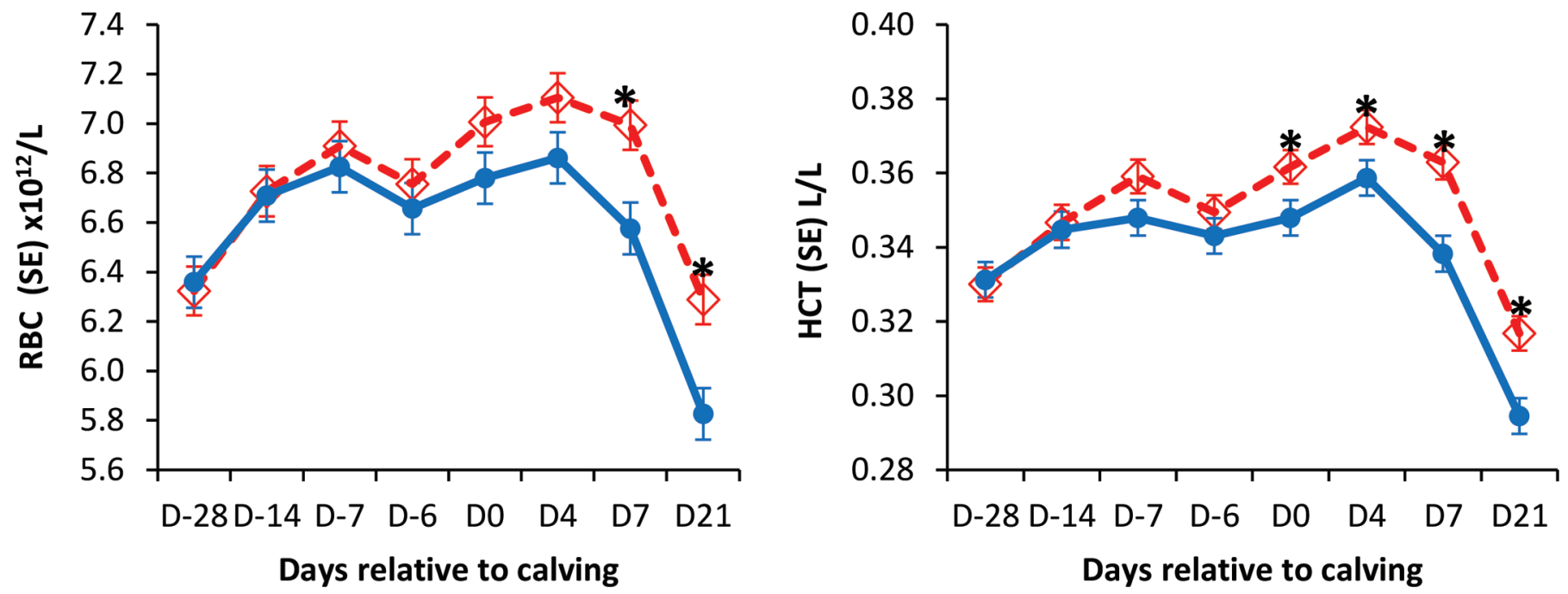

Figure 4. Covariate-adjusted (marginal) mean (SE) (left) red blood cell (RBC) count $\left(\times 10^{12} / \mathrm{L}\right)$ and (right) hematocrit $(\mathrm{HCT}$; L/L) for cows treated with pegbovigrastim (solid line) on $\mathrm{d}-7$ and d 0 compared with cows treated with saline (dashed line). The asterisks indicate differences $(P<0.05)$ between pegbovigrastim and saline-treated cows on that day. Color version available online.

treated cows having higher MPO release than control cows on $\mathrm{d}+4$, but not $\mathrm{d}+7$ (Figure $5 \mathrm{f}$ ). No feed $\times$ treatment interaction was observed $(P=0.29)$.

\section{Biochemistry}

Fatty Acid Concentrations. The geometric mean fatty acid concentrations were not affected overall by feed group $(P=0.52)$, but they varied by day relative to calving, and a feed group $\times$ time interaction was seen, whereby cows in the RR group had higher fatty acid concentrations at $\mathrm{d}-14$ and $\mathrm{d}-7$ compared with the FR group at these times (Figure 6a). Fatty acid concentrations were not affected by pegbovigrastim $(P$ $=0.89 ;$ Figure $6 \mathrm{~b}$ ).

The number of cows with elevated fatty acid concentrations (i.e., $>0.4$ and $>1.0 \mathrm{mmol} / \mathrm{L}$ pre- or postpartum, respectively) was not different between feed

Table 3. Covariate-adjusted (marginal) mean (SE) percentage of neutrophils, lymphocytes, monocytes, eosinophils, and basophils for cows treated with pegbovigrastim on $\mathrm{d}-7$ and d 0 compared with cows treated with saline (control)

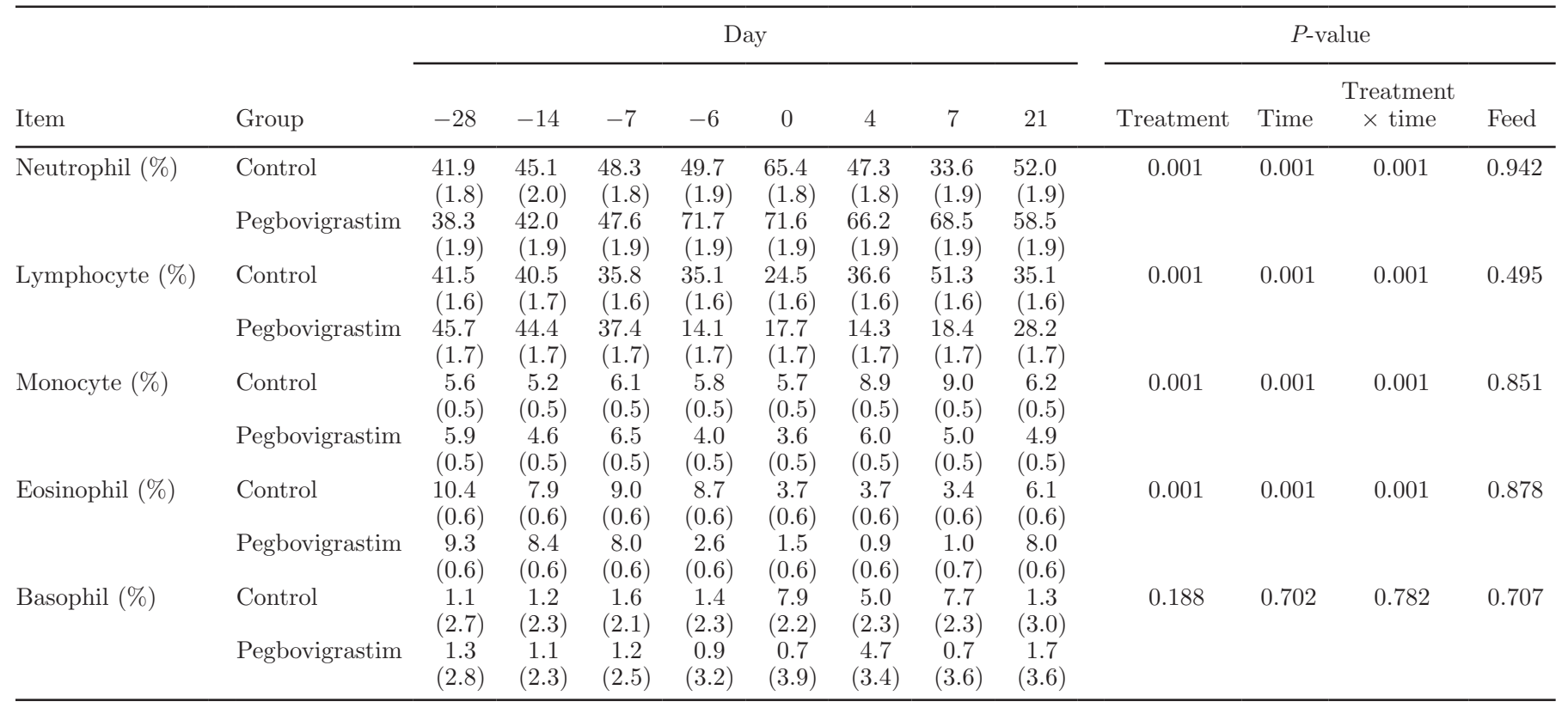


groups on $\mathrm{d}-28$, but more cows had elevated fatty acid in the RR group at $\mathrm{d}-14$ and $\mathrm{d}-7$ (Table 4 ).

BHB Concentrations. The geometric mean BHB concentrations were not affected overall by feed group $(P=0.94)$, but they varied by time, and a feed group $\times$ time interaction was noted whereby cows in the RR group had higher BHB concentration at $\mathrm{d}-7[0.42(95 \%$ CI: $0.37-0.47)$ vs. 0.35 (95\% CI: $0.31-0.39) \mathrm{mmol} / \mathrm{L}$ for $\mathrm{RR}$ vs. FR] but a lower BHB concentration at $\mathrm{d}+4$ compared with the FR group at this time $[1.02(95 \%$ (a)

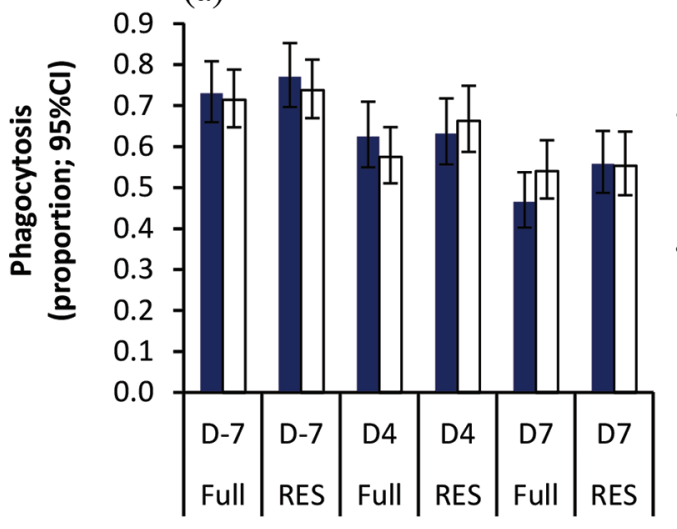

(c)

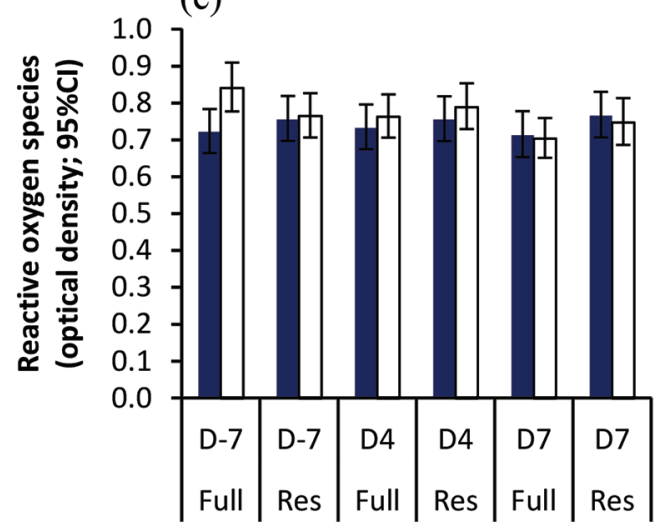

(e)

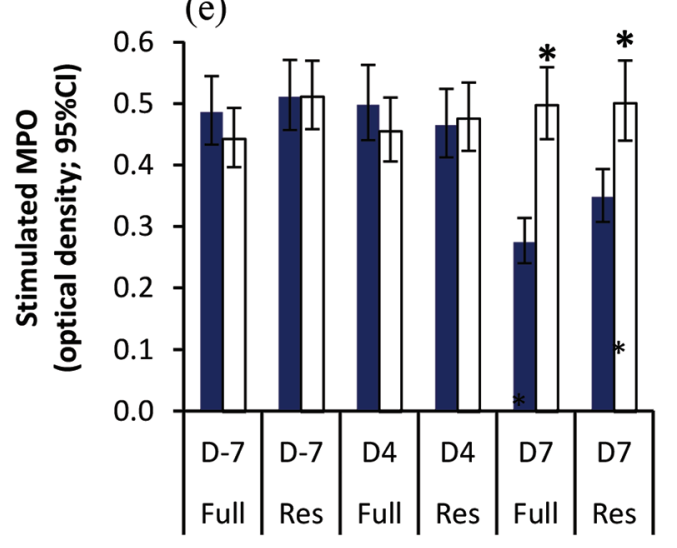

(b)

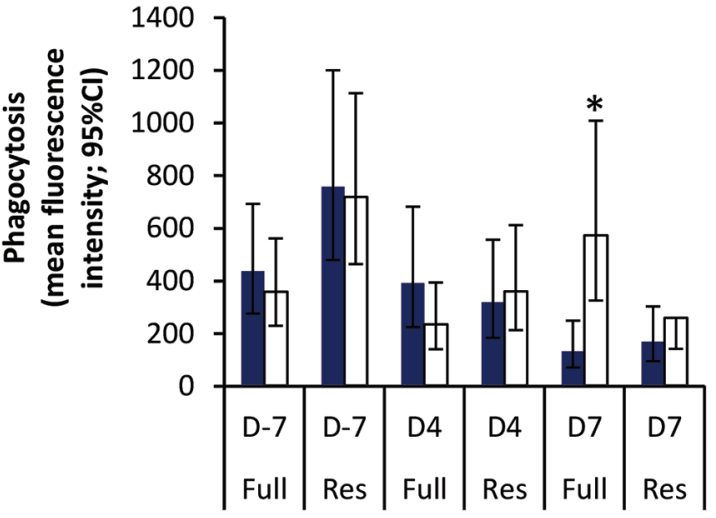

(d)

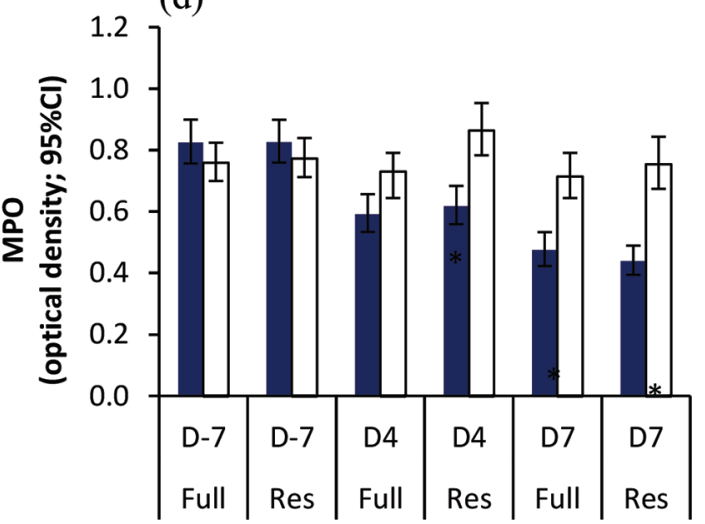

(f)

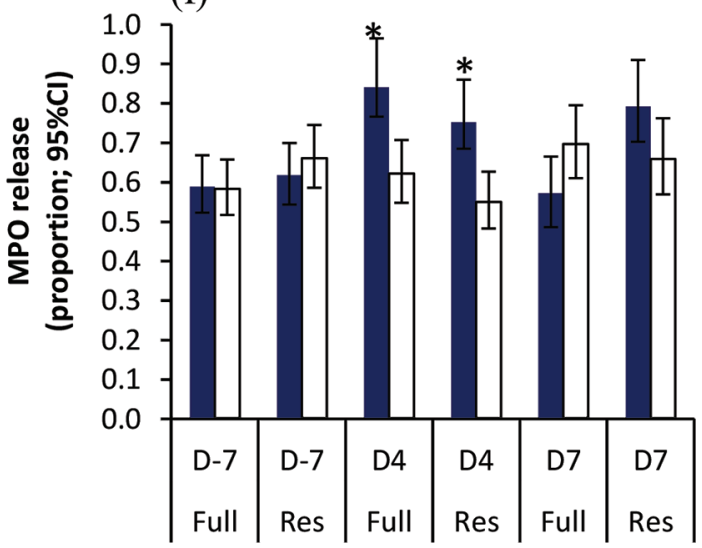

Figure 5. Geometric marginal means (95\% CI) for (a) phagocytosis, (b) phagocytosis mean florescence intensity, (c) reactive oxygen species, (d) myeloperoxidase (MPO) base optical density, (e) MPO-stimulated optical density, and (f) MPO release from blood neutrophils by day relative to calving $(\mathrm{d}-7,4,7)$, precalving feed intake (full vs. restricted, Res), and by treatment [pegbovigrastim (closed bar) vs. saline (open bar)]. Asterisks indicate significant differences $(P<0.05)$ between treatment groups within day and feed group. Color version available online. 
Table 4. The number (n) and percentage (\%) of cows with elevated ( $>0.4$ or $>1.0 \mathrm{mmol} / \mathrm{L}$ pre- and postpartum, respectively) serum fatty acid concentrations by day relative to calving (d 0) and by prepartum feed group

\begin{tabular}{lcccccc}
\hline & \multicolumn{2}{c}{ Restricted ration } & & \multicolumn{2}{c}{ Full ration } & \\
\cline { 2 - 3 } Day & $\mathrm{n}$ & $\%$ & & $\mathrm{n}$ & $\%$ & $\begin{array}{c}\text { Fisher's exact } \\
P \text {-value }\end{array}$ \\
\hline-28 & 15 & 36.6 & & 13 & 31.7 & 0.82 \\
-14 & 34 & 91.9 & & 15 & 40.5 & 0.01 \\
-7 & 35 & 85.4 & & 23 & 56.1 & 0.01 \\
4 & 33 & 82.5 & & 39 & 95.1 & 0.09 \\
7 & 35 & 92.1 & & 38 & 95.0 & 0.67 \\
\hline
\end{tabular}

CI: $0.91-1.15)$ vs. 1.23 (95\% CI: $1.09-1.38) \mathrm{mmol} / \mathrm{L}$ for RR vs. FR]. The BHB concentrations were not affected by pegbovigrastim treatment $(P=0.95)$.

No cow had a BHB $>0.8 \mathrm{mmol} / \mathrm{L}$ at $\mathrm{d}-28$, and 1 cow in each group had a BHB $>0.8$ on $\mathrm{d}-7$. A total of $10 / 40(25.0 \%)$ and $12 / 41(29.3 \%)$ of $\mathrm{RR}$ and FR cows, respectively, had BHB $>1.4 \mathrm{mmol} / \mathrm{L}$ at $\mathrm{d}+4(P$ $=0.67)$ and $9 / 38(23.7 \%)$ and $12 / 40(30.3 \%)$ of $\mathrm{RR}$ and FR cows, respectively, had BHB $>1.4 \mathrm{mmol} / \mathrm{L}$ at $\mathrm{d}+7(P=0.53)$. No association was observed between pegbovigrastim treatment and proportion of cows with BHB $>1.4 \mathrm{mmol} / \mathrm{L}$ on any day.

Calcium Concentrations. A total of 21 of 82 $(34.6 \%)$ and 8 of $78(10.2 \%)$ of cows had calcium concentrations of $<2 \mathrm{mmol} / \mathrm{L}$ on $\mathrm{d} 0$ and $\mathrm{d}+7$, respectively. The proportion of cows with calcium concentrations $<2 \mathrm{mmol} / \mathrm{L}$ did not differ between feed groups or treatment on either day $(P>0.3)$. Similarly feeding group had no effect on hypocalcemia, using the threshold for hypocalcemia of $<2.15 \mathrm{mmol} / \mathrm{L}$ proposed by Martinez et al. (2012) on d $0[26 / 41$ (63.4\%) vs. $22 / 41(53.7 \%)$; RR vs. FR, respectively; $P=0.50]$ or $\mathrm{d}+7[14 / 40(35.0 \%)$ vs. $14 / 38(36.8 \%)$ for RR vs. FR, respectively; $P=1.0]$. Pegbovigrastim had no effect on the proportion of cows with hypocalcemia (defined as $<2.15 \mathrm{mmol} / \mathrm{L})$ on $\mathrm{d} 0(P=0.26)$ or $\mathrm{d}+7(P=0.82)$. The calcium concentration was unaffected by feed $[2.17$ $(\mathrm{SE}=0.03)$ vs. $2.14(\mathrm{SE}=0.03) \mathrm{mmol} / \mathrm{L}$ for $\mathrm{RR}$ vs. $\mathrm{FR}, P=0.68]$ or treatment $[2.16(\mathrm{SE}=0.03)$ vs. 2.15 $(\mathrm{SE}=0.03) \mathrm{mmol} / \mathrm{L}$ for pegbovigrastim vs. control, $P$ $=0.82]$, but increased from $\mathrm{d} 0$ to $\mathrm{d}+7[2.07$ ( $\mathrm{SE}=$ $0.02)$ vs. $2.24(\mathrm{SE}=0.02) \mathrm{mmol} / \mathrm{L}$ for $\mathrm{d} 0$ vs. $\mathrm{d}+7$, $P<0.001$ ]. No first-order interactions were observed among these main effects (all $P>0.05$ ).

Associations Between Blood Metabolites and MPO Release. No associations were observed between MPO release and fatty acid concentration, time, or treatment, and no first- or second-order interactions occurred (all $P>0.3$ ).

At the bivariate level, MPO release was positively associated with $\log \mathrm{BHB}$ concentration, days relative to calving, and treatment. However, in a multivariable model with these 3 factors included, only treatment remained significant $(P=0.003)$, and no treatment $\times$ $\log$ BHB interaction was observed $(P=0.42)$.

No association occurred between MPO release and calcium concentration at the bi- or multivariate level $(P>0.2)$.

\section{DISCUSSION}

This study assessed the effect of precalving nutrition on the response to pegbovigrastim (pegylated bovine (a)

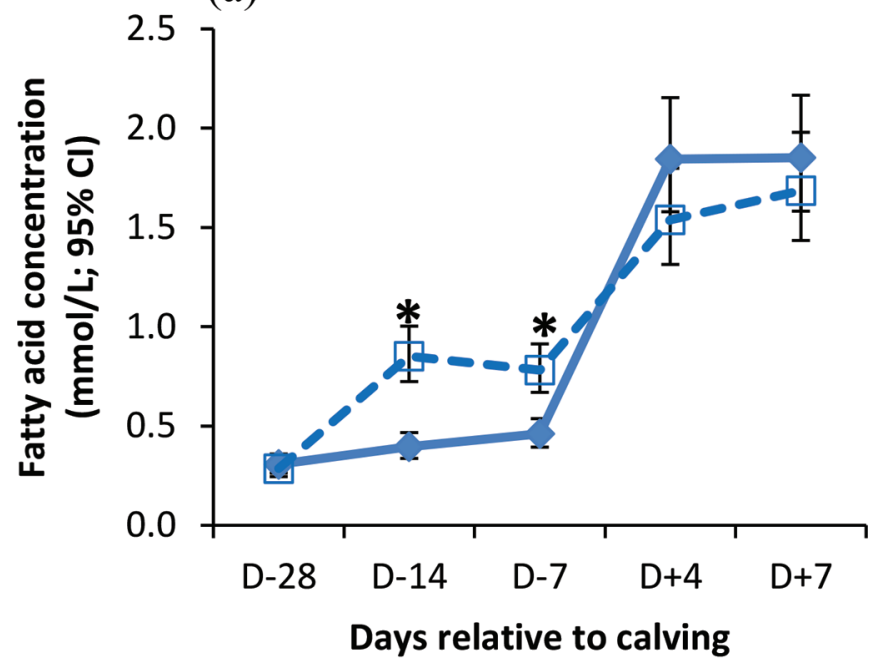

(b)

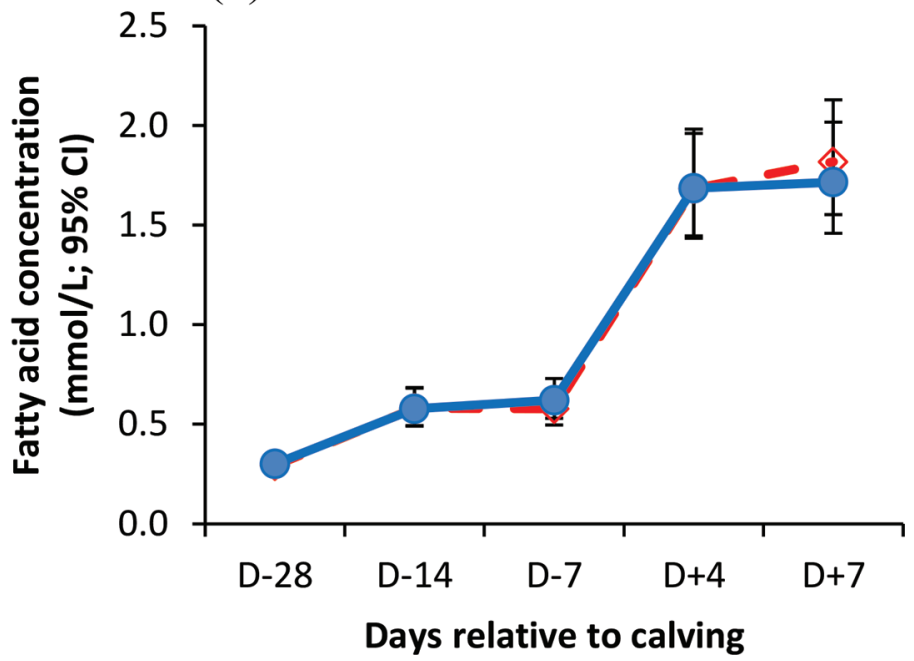

Figure 6. Geometric mean (95\% CI) serum fatty acid concentrations (mmol/L) for cows on (a) a restricted diet (dashed line) compared with those on full feed (solid line) from approximately 1 mo before calving, and (b) treated either with pegbovigrastim (solid line) or saline (dashed line). Asterisks indicate days where fatty acid concentrations differed between feed groups $(P<0.05)$. Color version available online. 
G-CSF) treatment. We hypothesized that restriction of prepartum energy intake may have reduced the response to pegbovigrastim. However, precalving energy restriction did not affect the response to pegbovigrastim treatment, as assessed by hematology or neutrophil function. This study is the first to assess the effect of precalving nutrition on response to pegbovigrastim. Additionally, this study is the first involving cattle in a pasture-grazed system, and it demonstrated that the response to pegbovigrastim in the pasture system was similar to that in previous studies using cattle fed on total mixed rations.

\section{Effect of Prepartum Nutrition on Pegbovigrastim Response}

The primary objective of this study was to assess whether negative energy balance prepartum affected the response to treatment with pegbovigrastim. The RR group was fed $85 \%$ of prepartum energy requirements, compared with $122 \%$ for the FR group, or a $37 \%$ difference in energy intakes. The diets offered in this study achieved underfeeding and overfeeding relative to an optimal prepartum intake. Although we did not formally measure energy balance, the BW and BCS data suggest that the FR group was getting adequate but not excessive energy intake because the BW increased only $1 \%$ (i.e., about $5 \mathrm{~kg}$ ) in the last month prepartum and the BCS was static. The prepartum feed restriction produced loss of BW and BCS, and prepartum fat mobilization. Notably, almost all cows $(85 \%)$ in the feedrestricted group had serum fatty acid concentrations $>0.4 \mathrm{mmol} / \mathrm{L}$ at $\mathrm{d}-7$ relative to calving. The fatty acid concentrations in the restricted group prepartum in the current study were similar to those reported from a New Zealand study in which cows were restricted to $65 \%$ of energy requirements (Roche et al., 2017), and higher than in a series of US studies in which $80 \%$ of maintenance energy was fed prepartum (Cardoso et al., 2013). In the current study, fatty acid concentrations were 0.85 and $0.78 \mathrm{mmol} / \mathrm{L}$ at 2 and 1 wk precalving in the restricted group. In comparison, the fatty acid concentrations were about $0.8 \mathrm{mmol} / \mathrm{L}$ in the New Zealand study (Roche et al., 2017) and 0.31 and $0.51 \mathrm{mmol} / \mathrm{L}$, respectively, at the same time points in the US studies (Cardoso et al., 2013). Intake estimates were partly based on DM intakes of pasture as measured using a rising plate meter. Where trampling of pasture occurs during grazing, the postgrazing pasture height may be underestimated, thus overestimating intakes. Given the changes in BW, BCS, and fatty acid concentrations, the restricted nutritional treatment likely resulted in more severe intake restrictions than those calculated.
A cut-point of serum fatty acid of $>0.4 \mathrm{mmol} / \mathrm{L}$ is associated with increased risk of ketosis, displaced abomasum, and metritis; reduced milk production; and pregnancy in early lactation (Chapinal et al., 2011; Ospina et al., 2013). Here, despite a high prevalence of cows above the threshold of fatty acid for elevated disease risk, the proportion of cows with elevated postpartum BHB in both diet groups was in the typical, expected range of 20 to $30 \%$. This distinction between the observed levels of fatty acid versus BHB likely reflects the lower milk yield of these cows relative to Holstein cows in high-producing herds in North America. Although fatty acid and BHB concentrations in wk -1 and +1 relative to calving are useful indicators of risk status for postpartum health, production, and reproduction, the single strongest predictor is serum fatty acid $>0.3$ to $0.5 \mathrm{mmol} / \mathrm{L}$ (depending on the outcome of interest) (LeBlanc et al., 2005; Ospina et al., 2010; Chapinal et al., 2011).

We underline that response to treatment with pegbovigrastim was not associated with serum fatty acid or BHB. Moreover, serum fatty acid or BHB concentrations did not modify the effect of pegbovigrastim, and few interactions of dietary treatment with pegbovigrastim treatment were observed. Therefore, save for the details discussed below, for this research question the present study provides evidence that the effects of pegbovigrastim treatment is not modulated by the cows' prepartum energy status.

Peripartum hypocalcemia was found to not affect neutrophil function in one study (Kehrli and Goff 1989), but a more recent study did associate hypocalcemia with reduced neutrophil function and increased fatty acid or BHB concentrations (Martinez et al., 2012). The current study found no association between calcium concentration and neutrophil number or function. Kimura et al. (2014) found that calcium concentrations were higher $2 \mathrm{~d}$ before calving and fatty acid concentrations were lower at d 10 after calving in pegbovigrastim-treated cows compared to control cows. These findings were not replicated in the current study. Calcium, fatty acid, and BHB concentrations changed as expected over time, but no interactions of these metabolic parameters with treatment were observed. Additionally, the effect of pegbovigrastim on neutrophil function as assessed by MPO release was not modified by the concentration of blood metabolites associated with nutritional status.

\section{Hematology}

Pegbovigrastim treatment was associated with elevated white cell and neutrophil count until at least 21 
DIM (the last sampling time). This outcome extends the findings of Kimura et al. (2014), who demonstrated elevations in neutrophil count out to 13 DIM. The white cells counts in untreated and treated cows were within the range of previous reports (Kehrli et al., 1991; Cullor et al., 1992; Kimura et al., 2014; Hassfurther et al., 2015). As expected, transient neutrophilia occurred on the day of calving in the control group, likely associated with increased endogenous glucocorticoid concentrations (Burton et al., 2005). This neutrophilia is initially due to glucocorticoid down-regulation of surface adhesion molecules and hence reduced diapedesis of neutrophils (Burton et al., 2005). The lower neutrophil count observed in the control cows at $\mathrm{d}+4$, and $\mathrm{d}+7$ may be associated with the recruitment of neutrophils to infected sites after entry of bacteria into the mammary gland and uterus.

We observed increases in monocyte counts at $\mathrm{d} 0, \mathrm{~d}$ +4 , and $\mathrm{d}+7$ postpartum unlike the studies of Cullor et al. (1990a,b) and Kimura et al. (2014). In mice, GCSF has been shown to bind to monocytes (Nicola and Metcalf, 1985). A 3-fold increase in monocytes occurs in humans following G-CSF treatment, and functional receptors for G-CSF have been detected on human monocytes (Boneberg et al., 2000).

The lymphocyte concentrations differed between pegbovigrastim-treated and control cows at $d-28$, that is, $3 \mathrm{wk}$ before treatment. This finding is likely due to chance. Lymphocytosis is associated with chronic infections, bovine leukemia virus (now eradicated from New Zealand), and lymphoid leukemia. In the latter disease, abnormal lymphocyte morphology would be expected. No cow was reported to have such abnormalities, thus undiagnosed leukemia would appear unlikely.

Pegbovigrastim treatment was associated with a lower red blood cell count on $\mathrm{d}+14$ and $\mathrm{d}+21$ and lower hematocrit on d 0 through to d 21 after calving, compared to controls. No effect on red blood cell parameters was reported following either short-term (8 daily doses) or long-term (46 daily doses) studies using $5 \mu \mathrm{g} / \mathrm{kg}$ recombinant bovine G-CSF (Kehrli et al., 1991). Hence the significance of the findings of the current study are not clear; although several of the red blood cell counts and hematocrits were above normal range, the differences seen are unlikely to be clinically important, but they may merit further investigation.

\section{Phagocytosis and Respiratory Burst}

In this study, the ability of blood neutrophils to perform phagocytosis, as tested in an in vitro functional assay, was reduced following calving as indicated by a lower number of phagocytosing neutrophils as well as reduced endocytosis per cell. Pegbovigrastim treatment did not affect these functions in individual neutrophils. Similarly, oxidative burst was not affected by pegbovigrastim treatment, time, or feed.

The percentage of phagocytic neutrophils as well as MFI were similar to earlier studies (Moya et al., 2008; Kimura et al., 2014). Previous studies also observed impairments of neutrophil phagocytosis during the peripartum period, which was at least partly reversed by G-CSF treatment (Kehrli et al., 1991). In vitro pre-incubation of neutrophils with G-CSF resulted in increased phagocytosis and respiratory burst (Mitchell et al., 2003). Treatment with G-CSF significantly enhanced the phagocytic function of both circulating and peritoneal neutrophils of rats with abdominal sepsis (Zhang et al., 1998). A study in rabbits suggested that G-CSF treatment causes the bone marrow to release neutrophils that preferentially sequestered in lung microvessels but were slow to migrate out of the vascular space into the airspace at the pneumonic site (van Eeden et al., 2000). In in vitro studies, elevated concentrations of fatty acids have been shown to increase phagocytosis-associated oxidative burst and reduce cell viability (Scalia et al., 2006; Ster et al., 2012). In contrast, BHB inhibited the respiratory burst in vitro in some studies (Hoeben et al., 1997), but not others (Ster et al., 2012). Granulocyte colony-stimulating factor primed bovine neutrophils for superoxide production induced by bovine IgG (Tao et al., 1995), and it increased the respiratory burst in neutrophils from human neonates (Drossou-Agakidou et al., 1998). However, a recent study of pegbovigrastim-treated transition cows did not show an effect of pegbovigrastim treatment on phagocytosis or respiratory burst by neutrophils (Kimura et al., 2014).

Based on the results of this study and in the context of previous studies, we conclude that during transition, neutrophils show an impaired ability to phagocytose pathogens and perform respiratory burst that can be at least partly reversed by pegbovigrastim treatment.

\section{Degranulation}

During degranulation, neutrophils release an assortment of effector molecules that have antimicrobial properties. One of the molecules involved is MPO, which produces hypochlorous acid from hydrogen peroxide and chloride anion during the neutrophil's respiratory burst. Myeloperoxidase mRNA expression was first detected in freshly isolated and in vitro G-CSF-treated human neutrophils (Berliner et al., 1995), but the regulation of MPO synthesis and release is still very poorly understood (Hansson et al., 2006).

In the current study, the ability of blood neutrophils to release MPO was affected by time. As reported pre- 
viously, MPO exocytosis was decreased after calving (Kehrli et al., 1991; Kimura et al., 1999, 2002, 2014). The total content and stimulated extracellular release of MPO was decreased after calving. This effect was more pronounced in pegbovigrastim-treated animals, as reported previously (Kimura et al., 2014). Healthy human subjects injected with recombinant human GCSF had increased plasma levels of MPO (Morabito et al., 2005), likely from moderate in vivo exocytosis of MPO from neutrophils. The lower total and secreted MPO in neutrophils from pegbovigrastim-treated cows may be caused by the same mechanism. Although total MPO in neutrophils from pegbovigrastim-treated cows was lower, the relative release of MPO was higher than observed with control animals, which has also been shown in a previous study (Kimura et al., 2014). The remaining intracellular MPO was apparently released more efficiently from the already primed neutrophils of pegbovigrastim-treated cows.

\section{CONCLUSIONS}

This study demonstrated that calving and treatment with pegbovigrastim modulate circulating neutrophil numbers and function in vitro. Pegbovigrastim injection treatment resulted in increased neutrophil counts and enhanced MPO release. Substantial energy deficiency in the month before calving had little effect on basal and stimulated neutrophil function, and the results show that the response to pegbovigrastim injection is not blunted by peripartum energy intake restriction.

\section{ACKNOWLEDGMENTS}

The assistance of the Massey University farm staff including Hamish Doohan and Fiona Brown, the technical staff of Institute of Veterinary, Animal and Biomedical Sciences, Massey University (Jenny Nixey), the laboratory staff from New Zealand Veterinary Pathology at Palmerston North, and the technicians from Cognosco (Cathy Yanez, Elizabeth Blythe) are gratefully acknowledged. Clinical examination and sampling of cattle was undertaken by veterinarians at IVABS including Richard Laven, Kevin Lawrence, Kristina Mueller, and Lisa Whitfield. Funding was provided by Elanco Animal Health (Greenfield, IN).

\section{REFERENCES}

Avalos, B. R. 1996. Molecular analysis of the granulocyte colony-stimulating factor receptor. Blood 88:761-777.

Bendall, L. J., and K. F. Bradstock. 2014. G-CSF: From granulopoietic stimulant to bone marrow stem cell mobilizing agent. Cytokine Growth Factor Rev. 25:355-367.
Berliner, N., A. Hsing, T. Graubert, F. Sigurdsson, M. Zain, E. Bruno, and R. Hoffman. 1995. Granulocyte colony-stimulating factor induction of normal human bone marrow progenitors results in neutrophil-specific gene expression. Blood 85:799-803.

Boneberg, E.-M., L. Hareng, F. Gantner, A. Wendel, and T. Hartung. 2000. Human monocytes express functional receptors for granulocyte colony-stimulating factor that mediate suppression of monokines and interferon- $\gamma$. Blood 95:270-276.

Burton, J. L., S. A. Madsen, L.-C. Chang, P. S. D. Weber, K. R. Buckham, R. van Dorp, M.-C. Hickey, and B. Earley. 2005. Gene expression signatures in neutrophils exposed to glucocorticoids: A new paradigm to help explain "neutrophil dysfunction" in parturient dairy cows. Vet. Immunol. Immunopathol. 105:197-219.

Cardoso, F. C., S. J. LeBlanc, M. R. Murphy, and J. K. Drackley. 2013. Prepartum nutritional strategy affects reproductive performance in dairy cows. J. Dairy Sci. 96:5859-5871.

Chapinal, N., M. Carson, T. F. Duffield, M. Capel, S. Godden, M. W. Overton, J. E. P. Santos, and S. J. LeBlanc. 2011. The association of serum metabolites with clinical disease during the transition period. J. Dairy Sci. 94:4897-4903.

Compton, C. W., L. Young, and S. McDougall. 2015. Subclinical ketosis in post-partum dairy cows fed a predominantly pasture-based diet: Defining cut-points for diagnosis using concentrations of beta-hydroxybutyrate in blood and determining prevalence. N. Z . Vet. J. 63:241-248.

Cullor, J. S., N. Fairley, W. Smith, S. L. Wood, J. D. Dellinger, M. S. Inokuma, and L. Souza. 1990a. Hemogram changes in lactating dairy cows given human recombinant granulocyte colony stimulating factor (r-MethuG-CSF). Vet. Pathol. 27:311-316.

Cullor, J. S., W. Smith, N. Fairley, S. L. Wood, J. D. Dellinger, and L. Souza. 1990b. Effects of human recombinant granulocyte colony stimulating factor (HR-GCSF) on the hemogram of lactating dairy cattle. Vet. Clin. Pathol. 19:9-12.

Cullor, J. S., W. Smith, J. G. Zinkl, J. D. Dellinger, and T. Boone. 1992. Hematologic and bone marrow changes after short- and long-term administration of two recombinant bovine granulocyte colony-stimulating factors. Vet. Pathol. 29:521-527.

Dale, D. C., W. C. Liles, W. R. Summer, and S. Nelson. 1995. Granulocyte colony-stimulating factor-Role and relationship in infectious diseases. J. Infect. Dis. 172:1061-1175.

Demetri, G. D., and J. D. Griffin. 1991. Granulocyte colony-stimulating factor and its receptor. Blood 78:2791-2808.

Drossou-Agakidou, V., F. Kanakoudi-Tsakalidou, K. Sarafidis, A. Taparkou, V. Tzimouli, H. Tsandali, and G. Kremenopoulos. 1998. Administration of recombinant human granulocyte-colony stimulating factor to septic neonates induces neutrophilia and enhances the neutrophil respiratory burst and beta2 integrin expression. Results of a randomized controlled trial. Eur. J. Pediatr. 157:583-588.

Earle, D. F., and A. A. McGowan. 1979. Evaluation and calibration of a rising plate meter for estimating pasture dry matter yield. Aust. J. Exp. Agric. Anim. Husb. 19:337-343.

Gilbert, R. O., Y. T. Gröhn, P. M. Miller, and D. J. Hoffman. 1993. Effect of parity on periparturient neutrophil function in dairy cows. Vet. Immunol. Immunopathol. 36:75-82.

Hansson, M., I. Olsson, and W. M. Nauseef. 2006. Biosynthesis, processing, and sorting of human myeloperoxidase. Arch. Biochem. Biophys. 445:214-224.

Hassfurther, R. L., T. N. TerHune, and P. C. Canning. 2015. Efficacy of polyethylene glycol-conjugated bovine granulocyte colonystimulating factor for reducing the incidence of naturally occurring clinical mastitis in periparturient dairy cows and heifers. Am. J. Vet. Res. 76:231-238.

Hoeben, D., R. Heynemann, and C. Burvenich. 1997. Elevated levels of beta-hydroxybutyric acid in periparturient cows and in vitro effect on respiratory burst activity of bovine neutrophils. Vet. Immunol. Immunopathol. 58:165-170.

Ingvartsen, K. L., R. J. Dewhurst, and N. C. Friggens. 2003. On the relationship between lactational performance and health: Is it yield or metabolic imbalance that cause production diseases in dairy cattle? A position paper. Livest. Prod. Sci. 83:277-308. 
Ingvartsen, K. L., and K. Moyes. 2013. Nutrition, immune function and health of dairy cattle. Animal 7:112-122.

Kehrli, M. E. Jr., and J. P. Goff. 1989. Periparturient hypocalcemia in cows: Effects on peripheral blood neutrophil and lymphocyte function. J. Dairy Sci. 72:1188-1196.

Kehrli, M. E., J. P. Goff, M. G. Stevens, and T. C. Boone. 1991. Effects of granulocyte colony-stimulating factor administration to periparturient cows on neutrophils and bacterial shedding. J. Dairy Sci. 74:2448-2458.

Kehrli, M. E., B. J. Nonnecke, and J. A. Roth. 1989. Alterations in bovine neutrophil function during the periparturient period. Am. J. Vet. Res. 50:207-214.

Kimura, K., J. P. Goff, P. Canning, C. Wang, and J. A. Roth. 2014 Effect of recombinant bovine granulocyte colony-stimulating factor covalently bound to polyethylene glycol injection on neutrophil number and function in periparturient dairy cows. J. Dairy Sci. 97:4842-4851.

Kimura, K., J. P. Goff, and M. E. Kehrli. 1999. Effects of the presence of the mammary gland on expression of neutrophil adhesion molecules and myeloperoxidase activity in periparturient dairy cows. J. Dairy Sci. 82:2385-2392.

Kimura, K., J. P. Goff, M. E. Kehrli, and T. A. Reinhardt. 2002. Decreased neutrophil function as a cause of retained placenta in dairy cattle. J. Dairy Sci. 85:544-550.

Kluciński, W., W. Degorski, E. Miernik-Degorska, S. Targowski, and A. Winnicka. 1988. Effect of ketone bodies on the phagocytic activity of bovine milk macrophages and polymorphonuclear leukocytes. Zentralbl. Veterinarmed. A 35:632-639.

LeBlanc, S. J. 2012. Interactions of metabolism, inflammation, and reproductive tract health in the postpartum period in dairy cattle. Reprod. Domest. Anim. 47(Suppl. 5):18-30.

LeBlanc, S. J., K. E. Leslie, and T. F. Duffield. 2005. Metabolic predictors of displaced abomasum in dairy cattle. J. Dairy Sci. $88: 159-170$.

Mallard, B. A., J. C. Dekkers, M. J. Ireland, K. E. Leslie, S. Sharif, C. L. Vankampen, L. Wagter, and B. N. Wilkie. 1998. Alteration in immune responsiveness during the peripartum period and its ramification on dairy-cow and calf health. J. Dairy Sci. 81:585-595.

Martin, C., P. C. E. Burdon, G. Bridger, J.-C. Gutierrez-Ramos, T. J. Williams, and S. M. Rankin. 2003. Chemokines acting via CXCR2 and CXCR4 control the release of neutrophils from the bone marrow and their return following senescence. Immunity 19:583-593.

Martinez, N., C. A. Risco, F. S. Lima, R. S. Bisinotto, L. F. Greco, E. S. Ribeiro, F. Maunsell, K. Galvão, and J. E. P. Santos. 2012. Evaluation of peripartal calcium status, energetic profile, and neutrophil function in dairy cows at restricted or high risk of developing uterine disease. J. Dairy Sci. 95:7158-7172.

Mitchell, G. B., B. N. Albright, and J. L. Caswell. 2003. Effect of interleukin-8 and granulocyte colony-stimulating factor on priming and activation of bovine neutrophils. Infect. Immun. 71:1643-1649.

Morabito, F., A. Tomaino, M. Cristani, M. Martino, P. L. Minciullo, A. Saija, and S. Gangemi. 2005. 'In vivo' time course of plasma myeloperoxidase levels after granulocyte colony-stimulating factorinduced stem cell mobilization. Transfus. Med. 15:425-428.

Moya, S. L., M. Alonso Gómez, L. A. Boyle, J. F. Mee, B. O'Brien, and S. Arkins. 2008. Effects of milking frequency on phagocytosis and oxidative burst activity of phagocytes from primiparous and multiparous dairy cows during early lactation. J. Dairy Sci. 91:587-595.

Moyes, K. M., J. K. Drackley, J. L. Salak-Johnson, D. E. Morin, J. C. Hope, and J. J. Loor. 2009. Dietary-induced negative energy balance has minimal effects on innate immunity during a Streptococcus uberis mastitis challenge in dairy cows during midlactation. J. Dairy Sci. 92:4301-4316.
Nickerson, S. C., W. E. Owens, and J. L. Watts. 1989. Effects of recombinant granulocyte colony-stimulating factor on Staphylococcus aureus mastitis in lactating dairy cows. J. Dairy Sci. 72:3286-3294.

Nicola, N. A., and D. Metcalf. 1985. Binding of ${ }^{125}$ I-labeled granulocyte colony-stimulating factor to normal murine hemopoietic cells. J. Cell. Physiol. 124:313-321.

Ospina, P. A., J. A. McArt, T. R. Overton, T. Stokol, and D. V. Nydam. 2013. Using nonesterified fatty acids and $\beta$-hydroxybutyrate concentrations during the transition period for herd-level monitoring of increased risk of disease and decreased reproductive and milking performance. Vet. Clin. North Am. Food Anim. Pract. $29: 387-412$

Ospina, P. A., D. V. Nydam, T. Stokol, and T. R. Overton. 2010 Evaluation of nonesterified fatty acids and $\beta$-hydroxybutyrate in transition dairy cattle in the northeastern United States: Critical thresholds for prediction of clinical diseases. J. Dairy Sci. 93:546554 .

Palić, D., C. B. Andreasen, B. W. Menzel, and J. A. Roth. 2005. A rapid, direct assay to measure degranulation of primary granules in neutrophils from kidney of fathead minnow (Pimephales promelas Rafinesque, 1820). Fish Shellfish Immunol. 19:217-227.

Roche, J. R., P. G. Dillon, C. R. Stockdale, L. H. Baumgard, and M. J. VanBaale. 2004. Relationships among international body condition scoring systems. J. Dairy Sci. 87:3076-3079.

Roche, J. R., A. Heiser, M. D. Mitchell, M. A. Crookenden, C. G. Walker, J. K. Kay, M. V. Riboni, J. J. Loor, and S. Meier. 2017. Strategies to gain body condition score in pasture-based dairy cows during late lactation and the far-off nonlactating period and their interaction with close-up dry matter intake. J. Dairy Sci. 100:1720-1738

Roth, J. A., D. E. Frank, P. Weighner, and M. Weighner. 2001. Enhancement of neutrophil function by ultrafiltered bovine whey. J. Dairy Sci. 84:824-829.

Roth, J. A., and M. L. Kaeberle. 1981. Isolation of neutrophils and eosinophils from the peripheral blood of cattle and comparison of their functional activities. J. Immunol. Methods 45:153-164.

Scalia, D., N. Lacetera, U. Bernabucci, U. Demeyere, L. Duchateau, and C. Burvenich. 2006. In vitro effects of nonesterified fatty acids on bovine neutrophils oxidative burst and viability. J. Dairy Sci. 89:147-154

Semerad, C. L., F. Liu, A. D. Gregory, K. Stumpf, and D. C. Link. 2002. G-CSF is an essential regulator of neutrophil trafficking from the bone marrow to the blood. Immunity 17:413-423.

Ster, C., M.-C. Loiselle, and P. Lacasse. 2012. Effect of postcalving serum nonesterified fatty acids concentration on the functionality of bovine immune cells. J. Dairy Sci. 95:708-717.

Suriyasathaporn, W., A. J. Daemen, E. N. Noordhuizen-Stassen, S. J. Dieleman, M. Nielen, and Y. H. Schukken. 1999. Beta-hydroxybutyrate levels in peripheral blood and ketone bodies supplemented in culture media affect the in vitro chemotaxis of bovine leukocytes. Vet. Immunol. Immunopathol. 68:177-186.

Tao, W., M. J. Corbett, and W. Pickett. 1995. Monomeric bovine IgG2 is a potent stimulus for bovine neutrophils. J. Leukoc. Biol. 58:203-208

van Eeden, S. F., E. Lawrence, Y. Sato, Y. Kitagawa, and J. C. Hogg. 2000. Neutrophils released from the bone marrow by granulocyte colony-stimulating factor sequester in lung microvessels but are slow to migrate. Eur. Respir. J. 15:1079-1086.

Zhang, P., G. J. Bagby, D. A. Stoltz, W. R. Summer, and S. Nelson. 1998. Enhancement of peritoneal leukocyte function by granulocyte colony-stimulating factor in rats with abdominal sepsis. Crit. Care Med. 26:315-321. 